\title{
Pengaruh Pembiayaan Musyarakah Terhadap Perkembangan Usaha Mikro dan Peningkatan Pendapatan Nasabah
}

\author{
U. Syafrudin, Mariana \\ Program Studi Perbankan Syariah FSEI IAIN Syekh Nurjati Cirebon \\ e-mail:mariana_a99@yahoo.co.id,ujangsyaf@gmail.com
}

\begin{abstract}
Abstrak
Keberadaan BMT sangat berperan dan berpengaruh bagi masyarakat kecil karena dapat dijadikan sebagai sumber modal yang dapat digunakan untuk meningkatkan usaha agar menjadi berkembang dari sebelumnya serta terjadi peningkatan pada pendapatannya, tambahan modal tersebut disebut dengan sistem pembiayaan musyarakah (profit sharing). Oleh sebab itu, penelitian ini bertujuan untuk mengatahui seberapa besar pengaruh pembiayaan musyarakah secara parsial terhadap usaha mikro dan peningkatan pendapatan nasabah di BMT Islamic Centre. Penelitian ini menggunakan pendekatan kuantitatif. Data yang digunakan dalam penelitian ini adalah data primer dengan teknik pengumpulan data melalui penyebaran angket. Dengan jumlah responden sebanyak 85 responden. Analisis data menggunakan regresi linier sederhana, dengan pengujian validitas, pengujian reliabilitas, dan analisis determinasi, sedangkan pengujian secara parsial menggunakan uji t. Selain itu dilakukan juga uji asumsi klasik, dimana semua pengujian tersebut menggunakan alat bantu program SPSS versi 21. Berdasarkan hasil uji validitas dan reliabilitas setiap item pernyataan pada variabel pembiayaan musyarakah, usaha mikro, dan pendapatan nasabah dinyatakan valid dan reliabel. Serta hasil dari uji asumsi klasik semua data terbebas dari uji normalitas dan uji linearitas. Pada uji t, variabel pembiayaan musyarakah secara parsial berpengaruh positif signifikan terhadap usaha mikro dengan nilai $t_{\text {hitung }}>t_{\text {tabel }}(3,039>$ 1,663). Dan variabel pembiayaan musyarakah secara parsial berpengaruh positif signifikan terhadap pendapatan nasabah dengan nilai $t_{\text {hitung }}>t_{\text {tabel }}(2,231>1,663)$. Dan koefisien determinasi $\left(R^{2}\right)$ 10\% usaha mikro dipengaruhi oleh pembiayaan musyarakah serta 5,7\% pendapatan nasabah dipengaruhi oleh pembiayaan musyarakah. Sedangkan sisanya $90 \%$ usaha mikro dipengaruhi oleh faktor lain yang tidak dicantumkan dalam penelitian ini, begitupun dengan pendapatan nasabah sebesar 94,3\% sisanya dipengaruhi oleh faktor lain juga.
\end{abstract}

Kata Kunci: Pendapatan Nasabah, Usaha Mikro, dan Pembiayaan Musyarakah

\begin{abstract}
The existence of BMT is very important and influential for the small community because it can be used as a source of capital that can be used to increase its business to be developed from the previous and there is an increase in income, additional capital is called the system of musyarakah financing (profit sharing). Therefore, this study aims to determine how much influence partial financing of musyarakah to micro business and increase customer income in BMT Islamic Center. This research uses quantitative approach. The data used in this study is primary data with data collection techniques through questionnaires.
\end{abstract}


With the number of respondents as many as 85 respondents. Data analysis used simple linear regression, with validity testing, reliability testing, and determination analysis, while the test partially using the t test. In addition it is also done the classical assumption test, where all the tests using tools SPSS program version 21. Based on the results of validity and reliability test each item statement on musyarakah financing variables, micro business, and customer income declared valid and reliable. As well as the results of the classical assumption test all data are free of normality test and linearity test. In t-test, musyarakah financing variable partially significant to micro business with tcount> ttable (3,039> 1,663). And musyarakah financing variables partially significant effect on customer's income with tcount> ttable (2,231> 1,663). And the coefficient of determination (R2) $10 \%$ of micro business is influenced by musyarakah financing and 5.7\% of customer's income is influenced by musyarakah financing. While the remaining $90 \%$ of micro business is influenced by other factors not listed in this study, as well as with customer income of $94.3 \%$ the rest is influenced by other factors as well.

Keywords: Customer Revenue, Micro Business, and Musyarakah Financing

\section{Pendahuluan}

Belakangan ini istilah pemberdayaan ekonomi rakyat atau Usaha Kecil Menengah (UKM) menjadi topik pembicaraan banyak kalangan. Sektor UKM ini mempunyai peranan yang sangat strategis dalam struktur perekonomian Nasional. Ketahanan tersebut disebabkan oleh tidak bergantungnya usaha mikro dan menengah pada bahan baku impor sehingga saat harga bahan baku impor melambung sejalan dengan melemahnya kurs rupiah, usaha mikro dan menengah terus berproduksi dengan harga relatif stabil karena sebagian besar menggunakan bahan baku lokal dari dalam negeri. ${ }^{1}$

Meskipun UKM menjanjikan bagi masa depan ekonomi nasional, namun dalam perkembangannya seringkali diperhadapkan oleh berbagai dilema. Persoalan pendanaan merupakan salah satu dilema yang sangat krusial bagi kelanjutan UKM. Lembaga keuangan non bank (BMT) yang diharapkan sebagai sumber pendanaan bagi perkembangan ekonomi UKM telah gagal memainkan fungsi dasarnya, terutama dalam menyalurkan dana secara efektif ke kegiatan-

${ }^{1}$ Hadinoto, Soetanto, Kiat Memimpin Bank Ritel, Mikro, dan Konsumer (Jakarta: PT. Elex Media Komputindo, 2009), hlm. 8 kegiatan usaha yang paling produktif atau paling menguntungkan secara finansial. ${ }^{2}$

Masyarakat sekarang ini banyak yang ingin memenuhi kebutuhan terutama bagi para pengusaha kecil yang sangat membutuhkan pemberian kredit. Dalam Islam, kredit harus bersifat bantuan dan bukan merupakan transaksi komersial.

Pendapatan merupakan hal yang penting, karena pendapatan ini menjadi objek atas kegiatan usaha, semakin tinggi penghasilan dan keuntungan maka akan semakin tinggi pula pendapatan yang didapat.

Dewasa ini lembaga keuangan sangat berperan dalam membangun perekonomian di Indonesia. Pembangunan dibidang ekonomi antara lain diarahkan untuk menumbuhkan peranan dan tanggung jawab masyarakat, untuk berperan secara nyata dalam pembangunan, serta memetik dan menikmati hasil pembangunan guna meningkatkan taraf hidup.

Bank merupakan salah satu lembaga keuangan yang mempunyai peranan penting di dalam perekonomian suatu negara sebagai badan usaha yang menghimpun dana dari masyarakat dalam bentuk simpanan dan

\footnotetext{
${ }^{2}$ Muhammad, "Bank Syariah Problem dan Prospek Perkembangan di Indonesia” (Yogyakarta: Graha Ilmu, 2005), hlm. 119
} 
menyalurkannya kepada masyarakat dalam bentuk kredit atau bentuk-bentuk lainnya dalam rangka meningkatkan taraf hidup rakyat banyak. $^{3}$

Dilihat dari segi imbalan maupun jasa atas penggunaan dana, baik simpanan maupun pinjaman, menurut peraturan Bank Indonesia No. 9/7/PBI/2007 Bank dibedakan menjadi dua yaitu bank konvensional dan bank syariah. Hal mendasar yang membedakan antara lembaga keuangan konvensional dengan syariah adalah terletak pada pengembalian dan pembagian keuntungan yang diberikan oleh nasabah kepada lembaga keuangan dan atau yang diberikan oleh lembaga keuangan kepada nasabah. Pertumbuhan dan perkembangan perbankan syariah di Indonesia tumbuh makin pesat secara fantastis. Krisis keuangan global disatu sisi telah membawa hikmah bagi perkembangan Perbankan Syariah. Prospek Perbankan Syariah di Indonesia makin cerah dan menjanjikan. Bank Syariah di Indonesia diyakini akan terus tumbuh dan berkembang. Perkembangan industri lembaga syariah ini diharapkan mampu memperkuat stabilitas sistem keuangan Nasional. ${ }^{4}$

Disamping Bank Syariah ada juga lembaga keuangan non bank yang bergerak dibidang syariah, salah satu diantaranya adalah Baitul Maal Wattamwil (BMT). Dengan kegiatan mengembangkan usahausaha produktif dan investasi dalam meningkatkan kualitas kegiatan ekonomi pengusaha kecil dengan antara lain mendorong kegiatan menabung dan menunjang pembiayaan kegiatan ekonominya. Baitul Maal wat Tamwil juga bisa menerima titipan zakat, infaq, dan sedekah, serta menyalurkannya sesuai dengan peraturan dan amanatnya.

\footnotetext{
${ }^{3}$ Soemitra, Andri, "Bank dan Lembaga Keuangan Syariah” (Jakarta: Kencana Prenada Media Group, 2009), hlm. 35

4 Budisantoso, Totok, "Bank dan Lembaga Keuangan lain edisi 2: Bank Umum Berdasar Prinsip Syari'ah” (Jakarta: Penerbit Salemba Empat, 2006), hlm. 56-58
}

Dengan demikian, keberadaan BMT dapat dipandang memiliki dua fungsi utama, yaitu sebagai media penyalur pendayagunaan harta ibadah seperti zakat, infaq, sedekah dan wakaf, serta dapat pula berfungsi sebagai institusi yang bergerak dibidang investasi yang bersifat produktif sebagaimana layaknya bank. Pada fungsi kedua ini dapat dipahami bahwa selain berfungsi sebagai lembaga keuangan, BMT juga berfungsi sebagai lembaga ekonomi. Sebagai lembaga keuangan BMT bertugas menghimpun dana dari masyarakat (anggota BMT) yang mempercayakan dananya disimpan di BMT dan menyalurkan dana kepada masyarakat (anggota BMT) yang diberikan pinjaman oleh BMT. Sedangkan sebagai lembaga ekonomi, BMT berhak melakukan kegiatan ekonomi, seperti mengelola kegiatan perdagangan, industri, dan pertanian. ${ }^{5}$

Pengembangan BMT sendiri merupakan hasil prakarsa dari Pusat Inkubasi Bisnis Usaha Kecil dan Menengah (PINBUK) yang merupakan badan pekerja yang dibentuk oleh Yayasan Inkubasi Usaha Kecil dan Menengah (YINBUK). YINBUK sendiri dibentuk oleh Ketua Umum Majelis Ulama Indonesia (MUI), Ketua Umum Ikatan Cendekiawan Muslim se-Indonesia (ICMI), dan Direktur Utama Bank Muamalat Indonesia (BMI) dengan akta notaris Leila Yudoparipurno, SH. Nomor 5 tanggal 13 Maret $1995{ }^{6}$

Selain kegiatan yang berhubungan dengan keuangan, BMT dapat juga mengembangkan usaha di bidang sektor riil, seperti kios telepon, kios benda pos, memperkenalkan teknologi maju untuk peningkatan produktivitas hasil para anggota, mendorong tumbuhnya industri rumah tangga atau pengolahan hasil, mempersiapkan jaringan perdagangan atau pemasaran masukan dan hasil produksi, serta

\footnotetext{
${ }^{5}$ Soemitra, Andri, "Bank dan Lembaga Keuangan Syariah" (Jakarta: Kencana Prenada Media Group, 2009), hlm. 452

${ }^{6}$ Soemitra, Andri, ”Bank dan Lembaga Keuangan Syariah” (Jakarta: Kencana Prenada Media Group, 2009), hlm. 445
} 
usaha lain yang layak, menguntungkan dan tidak mengganggu program jangka pendek, dengan syarat dikelola dengan sistem manajemen yang terpisah dan profesional. Usaha sektor riil BMT tidak boleh menyaingi usaha anggota tetapi justru akan mendukung dan memperlancar pengorganisasian secara bersama-sama keberhasilan usaha anggota dan kelompok anggota berdasarkan jenis usaha yang sama. Dan untuk mendukung kegiatan sektor riil anggota BMT, terdapat dua jenis kegiatan yang sangat mendasar yang perlu untuk dikembangkan oleh BMT. Pertama, mengumpulkan informasi dan sumber informasi tentang berbagai jenis kegiatan produktif unggulan untuk mendukung usaha kecil dan kelompok usaha anggota di daerah itu. Kedua adalah kegiatan mendapatkan informasi harga dan melembagakan kegiatan pemasaran yang efektif sehingga produkproduk hasil usaha anggota dan kelompok usaha dapat dijual dengan harga yang layak dan memenuhi jerih payah seluruh anggota keluarga yang bekerja untuk kegiatan tersebut. $^{7}$

Ada banyak produk penyaluran dana yang secara teknik finansial dapat dikembangkan pada sebuah lembaga keuangan Islam termasuk BMT, hal ini dimungkinkan karena sistem syariah memberi ruang yang cukup untuk itu. Namun pada praktiknya, sebagian besar BMT masih membatasi diri dengan menerapkan beberapa produk saja yang dianggap aman dan profitable.

Dari sekian banyak sistem pembiayaan usaha yang diterapkan, salah satunya adalah sistem pembiayaan musyarakah yang merupakan jalan alternatif terhadap para pedagang kecil yang mengajukan pembiayaan di BMT Islamic Centre, sebagaimana ditunjukkan oleh data Per tanggal 10 Februari 2017 sebagai berikut:

\footnotetext{
${ }^{7}$ Soemitra, Andri, "Bank dan Lembaga Keuangan Syariah” (Jakarta: Kencana Prenada Media Group, 2009), hlm. 464-465
}

\begin{tabular}{|r|c|}
\hline \multicolumn{1}{|c|}{ Jenis Pembiayaan } & $\begin{array}{c}\text { Jumlah } \\
\text { Nasabah }\end{array}$ \\
\hline Pembiayaan Mudharabah & 6 \\
\hline Pembiayaan Musyarakah & 555 \\
\hline Pembiayaan Murabahah & 72 \\
\hline Pembiayaan Ijarah & 262 \\
\hline Total & 895 \\
\hline
\end{tabular}

Sumber: BMT Islamic Centre Kab. Cirebon

Dari data tersebut, total nasabah pembiayaan pada BMT Islamic Centre per tanggal 10 Februari 2017 sebanyak 895 nasabah, yang mana pembiayaan musyarakah paling banyak dibandingkan dengan jenis pembiayaan lainnya, karena dengan pembiayaan tersebut mampu untuk meminimalkan tingkat resiko yang ada dan juga karena dengan implikasi.

Penerapan sistem musyarakah, sekurang-kurangnya dapat meringankan beban bunga. Prinsip musyarakah adalah dengan menggunakan prinsip bagi hasil sesuai dengan kesepakatan dan bagi rugi akan ditanggung sesuai dengan porsi dana masing-masing. ${ }^{8}$ Transaksi musyarakah ini dilandasi adanya keinginan para pihak yang bekerja sama untuk meningkatkan nilai aset yang mereka miliki secara bersama-sama dengan memadukan seluruh bentuk sumber daya baik yang berwujud maupun yan tidak berwujud. ${ }^{9}$

Seorang mitra tidak dibenarkan untuk menentukan bagian keuntungannya sendiri pada awal kontrak, karena hal itu melemahkan musyarakah dan melanggar prinsip keadilan. Sedangakn kerugian, para ulama sepakat bahwa kerugian harus dibagi diantara para mitra secara proporsional terhadap saham masing-masing dalam

\footnotetext{
${ }^{8}$ Anshori, Abdul Ghofur, "Hukum Perbankan Syariah” (Bandung: PT. Refika Aditama, 2009), hlm. 37

9 A. Karim, Adiwarman, "Bank Islam Analisis Fiqh dan Keuangan" (Jakarta: PT. Raja Grafindo Persada, 2013), hlm. 102
} 
modal. Mereka mendukung pendapat ini dengan perkataan Ali bin Abi Thalib r.a, "Keuntungan harus sesuai dengan yang mereka tentukan, sedangkan kerugian harus proporsional dengan modal mereka."10

Keempat Mazhab hukum sunni seluruhnya menegaskan, bahwa kontrak musyarakah didasarkan atas unsur "kepercayaan" (trust) bagi setiap partner. Berdasarkan ketentuan tersebut, setiap partner tidak dapat meminta jaminan dari partner yang lain. Menurut Sarakhsi, setiap partner mempercayakan dirinya lebih dari apa yang dipercayakan kepadanya. Adanya persyaratan dalam kontrak yang menghendaki jaminan akan menjadikan kontrak batal. ${ }^{11}$

Dalil yang menjadi landasan hukum syariah dalam pembiayaan musyarakah ini diantaranya tercantum dalam Q.S. Shaad:24, yaitu: ${ }^{12}$

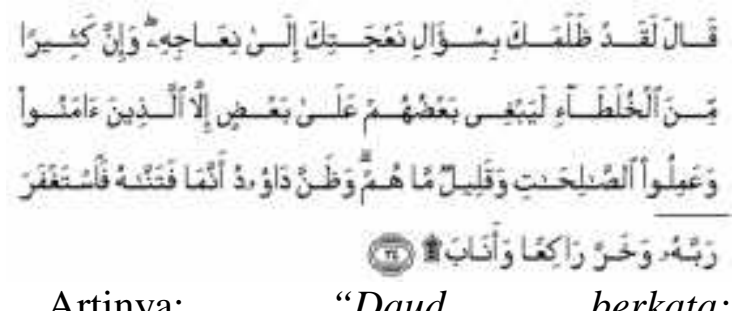

Artinya: "Daud berkata:

"Sesungguhnya dia telah berbuat zalim kepadamu dengan meminta kambingmu itu untuk ditambahkan kepada kambingnya.Dan sesungguhnya kebanyakan dari orang-orang yang berserikat itu sebagian mereka berbuat zalim kepada sebagian yang lain, kecuali orang-orang yang beriman dan mengerjakan amal yang saleh; dan amat sedikitlah mereka ini."

Serta dalam Hadits Riwayat Abu Daud dari Abu Hurairah:

10 Nawawi, Ismail, "Fiqh Muamalah Klasik dan Kontemporer" (Bogor: Ghalia Indonesia, 2012), hlm. 157

11 Saeed, Abdullah, "Bank Islam dan Bunga” (Yogyakarta: Pustaka Pelajar, 2003), hlm.110

12 Wirdyaningsih, dkk, "Bank dan Asuransi Islam di Indonesia” (Jakarta: Kencana, 2005), hlm. 119-120

$$
\begin{aligned}
& \text { عن أبي هريرة, رفعه قال : ان اله يقول : أنا } \\
& \text { ثالث الثركين, مالم يخن أحدهما صاحبه : اله } \\
& \text { فاذا خانه خرجت من بينهما (رواه أبوا داود } \\
& \text { و الحاكم عن أبي هريرة) }
\end{aligned}
$$

Artinya: "Dari Abu Huraira, ia merafa'kannya kepada Nabi, beliau bersabada: Aku (Allah) merupakan orang ketiga dalam perserikatan antara dua orang. Selama salah seorang di antara keduanya tidak melakukan pengkhianatan terhadap yang lain. Jika seseorang melakukan pengkhianatan terhadap yang lain, aku keluar dari perserikatan antara dua orang itu." 13

Jika pembiayaan musyarakah ini diterapkan sesuai dengan ketentuan syariah dan Peraturan Bank Indonesia yakni No: 7/46/PBI/2005 tentang akad penghimpunan dan penyaluran dana bagi bank yang melaksanakan kegiatan usaha berdasarkan prinsip syariah, telah ditetapkan bahwa dalam kegiatan penyaluran dana dalam bentuk pembiayaan berdasarkan musyarakah memberlakukan beberapa syarat-syarat tertentu, ${ }^{14}$ sehingga dengan terpenuhinya syarat-syarat tersebut serta dijalankan oleh para pelaku usaha dengan benar, maka pembiayaan tersebut berpotensi meningkatkan kegiatan usaha para pedagang kecil yang telah memperoleh pembiayaan musyarakah dari BMT Islamic Centre.

Karena salah satu tujuan BMT atau koperasi disamping memberdayakan perekonomian rakyat, industri lokal, juga membantu meningkatkan usaha ekonomi untuk kesejahteraan anggota pada khususnya dan masyarakat pada umumnya. ${ }^{15}$

Sehingga dengan diperolehnya dana dari pembiayaan musyarakah khususnya

${ }^{13}$ Nurul Huda dan Mohamad Heykal, "Lembaga Keuangan Islam Tinjauan Teoretis dan Praktis" (Jakarta: Kencana Prenada Media Group, 2010), hlm.67

14 Burhanuddin, "Aspek Hukum Lembaga Keuangan Syariah” (Yogyakarta: Graha Ilmu, 2010), hlm.68

${ }^{15}$ Soemitra, Andri, "Bank dan Lembaga Keuangan Syariah" (Jakarta: Kencana Prenada Media Group, 2009), hlm. 452 
oleh BMT Islamic Centre kepada para pelaku usaha mikro, diharapkan akan membantu mengembangkan usahanya serta mampu meningkatkan pendapatan nasabahnya itu sendiri. Adapun tujuan dalam penelitian ini adalah untuk mengetahui pengaruh penggunaan pembiayaan musyarakah terhadap perkembangan usaha kecil dan peningkatan pendapatan nasabah. Metode dalam penelitian ini menggunakan metode kuantitatif yang mempunyai tujuan menguji suatu teori, menyajikan suatu fakta atau mendeskripsikan statistik, menunjukkan hubungan variabel, dan ada yang bersifat mengembangkan konsep, mengembangkan pemahaman, atau mendeskripsikan banyak hal. Kemudian dianalisis yang umumnya menggunakan statistik dengan teknik analisis data regresi linier sederhana.

Pengembangan usaha adalah suatu proses pelaksanaan usaha mengenai peluang pertumbuhan potensial selama usaha itu berlangsung. Dalam hal ini perusahaan dapat memanfaatkan satu sama lain keahlian, teknologi atau kekayaan intelektual untuk memperluas kapasitas mereka untuk mengidentifikasi, meneliti, menganalisis dan membawa ke pasar bisnis baru dan produk baru, pengembangan bisnis berfokus pada implementasi dari rencana bisnis strategi melalui ekuitas pembiayaan, akuisisi/divestasi teknologi, produk, dan lain-lain. ${ }^{16}$

Perkembangan usaha merupakan suatu bentuk usaha untuk usaha itu sendiri agar dapat berkembang menjadi lebih baik untuk mencapai pada satu titik kesuksesan dan keuntungan. Perkembangan usaha akan dilihat dari proses jalannya usaha itu sendiri dan kemungkinan adanya usaha tersebut tumbuh dan berkembang.

Menurut Rudjito (2003) ${ }^{17}$ usaha mikro diartikan sebagai model usaha yang paling kecil, biasanya dilakukan di rumah

\footnotetext{
${ }^{16} \mathrm{http} / / /$ www.matabaraja.com/2016/10/p engertian-pengembangan-bisnismenurut.html diakses 22 Mei 2017 pkl 9.42 Arsyad, Lincolin, "Lembaga Keuangan Mikro" (Yogyakarta: Andi Offset, 2008), hlm. 124
}

dan sebagian besar tenaga kerjanya oleh kerabat keluarga, seperti dagang. Usaha kecil adalah kegiatan ekonomi rakyat yang berskala kecil dan memenuhi kriteria kekayaan bersih atau hasil penjualan tahunan serta kepemilikan.

Dalam pasal 1 ayat (1) UndangUndang Nomor 20 tahun 2008 tentang Usaha Mikro Kecil dan Menengah bahwa yang dimaksud "Usaha Mikro adalah usaha produktif milik orang perorangan dan atau badan usaha perorangan yang memenuhi usaha mikro, sebagaimana diatur dalam Undang-Undang ini."

Sedangkan dalam pasal 1 ayat (3) Undang-Undang Nomor 20 tahun 2008 tentang Usaha Mikro Kecil dan Menengah bahwa:

a. Usaha Mikro. Kriteria kelompok Usaha Mikro adalah usaha produktif milik orang perorangan dan atau badan usaha perorangan yang memenuhi kriteria Usaha Mikro sebagaimana diatur dalam undang-undang ini.

b. Usaha Kecil. Kriteria Usaha Kecil adalah usaha ekonomi produktif yang berdiri sendiri, yang dilakukan oleh orang perorangan atau badan usaha yang bukan merupakan anak perusahaan atau bukan cabang perusahaan yang dimiliki, dikuasai, atau menjadi bagian langsung maupun tidak langsung dari usaha menengah atau usaha besar yang memenuhi kriteria Usaha Kecil sebagaimana dimaksud dalam undangundang ini.

c. Usaha Menengah. Usaha Menengah adalah ekonomi produktif yang berdiri sendiri, yang dilakukan oleh orang perorangan atau badan usaha yang bukan merupakan anak perusahaan atau cabang perusahaan yang dimiliki, dikuasai atau menjadi bagian baik langsung maupun tidak langsung dengan usaha kecil atau besar dengan jumlah kekayaan bersih atau hasil penjualan tahunan sebagaimana diatur dalam undang-undang ini.

$$
\text { Adapun kriteria-kriteria yang }
$$
tergolong dalam UMKM adalah sebagai berikut: 
a. Kriteria Usaha Mikro, adalah sebagai berikut:

1. Memiliki kekayaan bersih paling banyak Rp. 50.000.000,- (lima puluh juta rupiah) termasuk tanah dan bangunan tempat usaha atau;

2. Memiliki hasil penjualan tahunan paling banyak Rp. 300.000.000,(tiga ratus juta rupiah).

b. Kriteria Usaha Kecil, adalah sebagai berikut:

1. Memiliki kekayaan bersih lebih dari Rp. 50.000.000,- (lima puluh juta rupiah) sampai dengan paling banyak Rp. 500.000.000,- (lima ratus juta rupiah) tidak termasuk tanah dan bangunan tempat usaha atau;

2. Memiliki hasil penjualan tahunan lebih dari Rp. 300.000.000,- (tiga ratus juta rupiah) sampai dengan paling banyak Rp. 2.500.000.000,(dua milyar lima ratus juta rupiah).

c. Kriteria Usaha Menengah, adalah sebagai berikut:

1. Memiliki kekayaan bersih lebih dari Rp. 500.000.000,- (lima ratus juta rupiah) sampai dengan paling banyak Rp. 10.000.000.000,(sepuluh milyar rupiah) tidak termasuk tanah dan bangunan tempat usaha atau;

2. Memiliki hasil penjualan tahunan lebih dari Rp. 2.500.000.000,(dua milyar lima ratus juta rupiah) sampai dengan paling banyak Rp. 50.000.000.000,- (lima puluh milyar rupiah).

Sesuai definisi di PSAK 23 (Revisi 2010) pendapatan adalah arus masuk kotor dari manfaat ekonomi yang timbul dari aktivitas normal entitas selama suatu periode jika arus masuk tersebut mengakibatkan kenaikan ekuitas yang tidak berasal dari kontribusi penanam modal.

Sedangkan yang dimaksud dengan nasabah menurut Undang-Undang No. 24 Tahun 2004 tentang Lembaga Penjamin Simpanan mengenal pengertian nasabah sebagaimana dijelaskan dalam Undang-
Undang No. 10 Tahun 1998 tentang Perubahan Atas Undang-Undang No. 7 Tahun 1992 tentang Perbankan, yaitu:

1. Pengertian nasabah penyimpan yaitu nasabah yang menempatkan dananya di bank dalam bentuk simpanan berdasarkan perjanjian bank dengan nasabah yang bersangkutan.

2. Pengertian nasabah debitur adalah nasabah yang memperoleh fasilitas kredit atau pembiayaan berdasarkan prinsip syariah atau yang dipersamakan dengan itu berdasarkan perjanjian bank dengan nasabah yang bersangkutan.

Jadi, yang dimaksud dengan pendapatan nasabah adalah penghasilan yang timbul dari aktivitas usaha, baik itu usaha barang atau jasa yang menyimpan atau meminjam uang pada bank. Semakin tinggi penghasilan dan keuntungan maka akan semakin tinggi pula pendapatan yang didapat.

Adapun faktor-faktor yang mempengaruhi pendapatan adalah sebagai berikut: $^{18}$

1. Kesempatan kerja yang tersedia, semakin banyak kesempatan kerja yang tersedia berarti semakin banyak penghasilan yang bisa diperoleh dari hasil kerja tersebut.

2. Jenis pekerjaan, terdapat banyak jenis pekerjaan yang dapat dipilih seseorang dalam melakukan pekerjaannya untuk mendapatkan penghasilan.

3. Kecakapan dan keahlian, dengan bekal kecakapan dan keahlian yang tinggi akan dapat meningkatkan efisiensi dan efektivitas yang pada akhirnya berpengaruh pula terhadap penghasilan.

4. Motivasi atau dorongan juga mempengaruhi jumlah penghasilan, semakin besar dorongan seseorang untuk melakukan pekerjaan semakin besar pula penghasilan yang diperoleh. Selain itu juga lokasi bekerja yang dekat dengan tempat tinggal dan kota akan membuat seseorang lebih semangat untuk bekerja.

18 Ratna, Sukmayanti, dkk, "Ilmu Pengetahuan Sosial” (Jakarta: Galaxy Puspa Mega, 2008), hlm. 117 
5. Keuletan kerja, pengertian keuletan dapat disamakan dengan ketekunan, keberanian untuk menghadapi segala macam tantangan. Bila saat menghadapi kegagalan maka kegagalan tersebut dijadikan sebagai bekal untuk meneliti kearah kesuksesan dan keberhasilan.

6. Banyak sedikitnya modal yang digunakan, besar kecilnya usaha yang dilakukan seseorang sangat dipengaruhi oleh besar kecilnya modal yang dipergunakan.

Dalam kegiatan perusahaan, pendapatan para pengusaha adalah keuntungan. Keuntungan ditentukan dengan cara mengurangkan berbagai biaya yang dikeluarkan dari hasil penjualan yang diperoleh. Biaya yang dikeluarkan meliputi pengeluaran untuk bahan mentah, pembayaran upah, pembayaran bunga, sewa tanah, dan penghapusan (depresiasi). Apabila hasil penjualan yang diperoleh dikurangi dengan biaya-biaya tersebut nilainya adalah positif maka diperolehlah keuntungan. ${ }^{19}$

Istilah pembiayaan pada intinya berarti I Believe, I Trust, 'saya percaya' atau 'saya menaruh kepercayaan'. Perkataan pembiayaan yang artinya kepercayaan (trust), berarti lembaga pembiayaan selaku shahibul maal menaruh kepercayaan kepada seseorang untuk melaksanakan amanah yang diberikan. Dana tersebut harus digunakan dengan benar, adil, dan harus disertai dengan ikatan dan syarat-syarat yang jelas, dan saling menguntungkan bagi kedua belah pihak, sebagaimana firman Allah SWT dalam surat An-Nisa: 29 dan surat AlMaidah: $1{ }^{20}$

Pasal 1 ayat (25) Undang-Undang Republik Indonesia Nomor 21 Tahun 2008 tentang Perbankan Syariah, menyatakan: pembiayaan adalah penyediaan dana atau tagihan yang dipersamakan dengan itu berupa:

19 Sukirno, Sadono, "Mikroekonomi Teori Pengantar” (Jakarta: PT Raja Grafindo Persada, 2013), hlm. 383-384

20 Rivai, Veithzal, "Islamic Financial Management” (Jakarta: PT Raja Grafindo, 2008), hlm. 3
1. Transaksi bagi hasil dalam bentuk mudharabah dan musyarakah.

2. Transaksi sewa-menyewa dalam bentuk ijarah atau sewa beli dalam bentuk ijarah muntahiya bittamlik.

3. Transaksi jual beli dalam bentuk piutang murabahah, salam, dan istishna.

4. Transaksi pinjam meminjam dalam bentuk piutang qardh.

5. Transaksi sewa-menyewa jasa dalam bentuk ijarah untuk transaksi multijasa.

Musyarakah berasal dari kata syirkah, yang artinya pencampuran atau interaksi. Sedangkan secara terminologi, syirkah adalah persekutuan usaha untuk mengambil hak atau untuk beroperasi. IAI dalam PSAK 106 mendefinisikan musyarakah sebagai akad kerja sama antara dua pihak atau lebih untuk suatu usaha tertentu dengan kondisi masing-masing pihak memberikan kontribusi dana, dengan ketentuan keuntungan dibagi berdasarkan kesepakatan, sedangkan kerugian berdasarkan kontribusi dana. ${ }^{21}$

Menurut arti asli bahasa arab, syirkah berarti mencampurkan dua bagian atau lebih sehingga tidak boleh dibedakan lagi satu bagian dengan bagian lainnya. ${ }^{22}$ Menurut Afzalur Rahman, seorang Deputy Secretary General in The Muslim School Trust, secara bahasa al-syirkah berarti alikhtilath (pencampuran) atau persekutuan dua orang atau lebih. Istilah lain dari musyarakah adalah sharikah atau syirkah atau kemitraan. ${ }^{23}$

Fatwa DSN No. 08/DSNMUI/IV/2000 mengatur mengenai
21 Yahya, Rizal, dkk, “Akuntansi Perbankan Syariah" (Jakarta: Salemba Empat, 2009), hlm. 136

22 Sudarsono, Heri, "Bank dan Lembaga Keuangan Syariah" (Yogyakarta: Ekonosia), hlm. 67

23 Sri Nurhayati dan Wasilah, "Akuntansi Syariah di Indonesia edisi 3" (Jakarta: PT.Salemba Empat, 2013), hlm. 150 
pembiayaan musyarakah dengan ketentuanketentuan sebagai berikut: ${ }^{24}$

a. Ijab kabul

Ijab kabul yang dinyatakan oleh para pihak harus memperhatikan hal-hal berikut:

1) Penawaran dan penerimaan harus secara eksplisit menunjukkan tujuan kontrak (akad);

2) Penerimaan dari penawaran dilakukan pada saat kontrak; dan

3) Akad dituangkan secara tertulis melalui korespondensi atau dengan menggunakan cara-cara komunikasi modern.

b. Subjek hukum

Para pihak yang berkontrak harus cakap hukum dan memperhatikan hal-hal berikut ini:

1) Kompeten dalam memberikan atau diberikan kekuasaan perwakilan.

2) Setiap mitra harus menyediakan dana dan pekerjaan, dan setiap mitra melaksanakan kerja sebagai wakil.

3) Setiap mitra memberi wewenang kepada mitra yang lain untuk mengelola aset dan masing-masing dianggap telah diberi wewenang untuk melakukan aktivitas musyarakah dengan memerhatikan kepentingan mitranya, tanpa melakukan kelalaian dan kesalahan yang disengaja.

4) Tidak diizinkan menggunakan dana untuk kepentingan sendiri.

c. Objek akad

Objek akad pada musyarakah terdiri dari modal, kerja, keuntungan, dan kerugian. Masing-masing ditentukan hal-hal berikut ini.

\section{1) Modal}

(a)Modal yang diberikan harus uang tunai, emas, perak, atau yang nilainya sama. Modal dapat terdiri dari aset perdagangan, seperti barang-barang, properti, dan

24 Wirdyaningsih, dkk, "Bank dan

Asuransi Islam di Indonesia” (Jakarta:

Kencana, 2005), hlm. 120-122 sebagainya. Jika modal berbentuk aset, harus terlebih dahulu dinilai dengan tunai dan disepakati oleh para mitra.

(b)Para pihak tidak boleh meminjam, meminjamkan, menyumbangkan atau menghadiahkan modal musyarakah kepada pihak lain, kecuali atas dasar kesepakatan.

(c) Pada prinsipnya, dalam pembiayaan musyarakah tidak ada jaminan, namun untuk menghindari terjadinya penyimpangan, maka Bank (LKS) diperkenankan meminta jaminan dari nasabah/mitra kerja.

2) Kerja

(a)Partisipasi para mitra dalam pekerjaan merupakan dasar pelaksanaan musyarakah, akan tetapi kesamaan porsi kerja bukanlah merupakan syarat. Seorang mitra boleh melaksanakan kerja lebih banyak dari yang lainnya, dan dalam hal ini ia boleh menuntut bagian keuntungan tambahan bagi dirinya.

(b)Setiap mitra melaksanakan kerja dalam musyarakah atas nama pribadi dan wakil dari mitranya. Kedudukan masing-masing dalam organisasi kerja harus dijelaskan dalam kontrak.

3) Keuntungan

(a) Keuntungan harus dikuantifikasi dengan jelas untuk menghindarkan perbedaan dan sengketa pada waktu alokasi keuntungan atau ketika penghentian musyarakah.

(b)Setiap keuntungan mitra harus dibagikan secara proporsional atas dasar seluruh keuntungan dan tidak ada jumlah yang ditentukan di awal yang ditetapkan bagi seorang mitra.

(c) Seorang mitra boleh mengusulkan, bahwa jika keuntungan melebihi jumlah tertentu, kelebihan atau presentasi itu diberikan kepadanya. 
(d)Sistem pembagian keuntungan harus tertuang dengan jelas dalam akad.

4) Kerugian

Kerugian harus dibagi diantara para mitra secara proporsional menurut saham masing-masing dalam modal.

d. Biaya persengketaan: ${ }^{25}$

dan

1) Biaya operasional dibebankan pada modal bersama; dan

2) Jika salah satu pihak tidak menunaikan kewajibannya atau jika terjadi perselisihan diantara para pihak, maka penyelesaiannya dilakukan melalui Badan Arbitrase Syariah setelah tidak tercapai kesepakatan melalui musyawarah.

Selain rukun musyarakah, terdapat juga syarat-syarat musyarakah yaitu: ${ }^{26}$

1. Ucapan: tidak ada bentuk khusus dari kontrak musyarakah, ia dapat berbentuk pengucapan yang menunjukkan tujuan. Berakad dianggap sah jika diucapkan secara verbal atau ditulis. Kontrak musyarakah dicatat dan disaksikan.

2. Pihak yang berkontrak: disyaratkan bahwa mitra harus kompeten dalam memberikan atau diberikan kekuasaan perwakilan.

3. Objek kontrak (dana dan kerja), dana atau modal yang diberikan harus uang tunai, emas, perak, atau yang bernilai sama. Para ulama menyepakati hal ini. Beberapa ulama memberi kemungkinan pula bila modal berwujud aset perdagangan, seperti barang-barang, properti, perlengkapan, dan sebagainya. Bahkan dalam bentuk hak yang tidak terlihat, seperti lisensi, hak paten, dan sebagainya. Bila itu ditakutkan, menurut kalangan ulama, seluruh modal

\footnotetext{
25 Nurul Huda dan Mohamad Heykal, "Lembaga Keuangan Islam:Tinjauan teoretis dan praktis" (Jakarta: Kencana, 2010), hlm. 69

26 Nawawi, Ismail, "Fiqh Muamalah Klasik dan Kontemporer" (Bogor: Ghalia Indonesia, 2012), hlm. 155
}

tersebut harus dinilai lebih dahulu secara tunai dan disepakati oleh mitranya.

$$
\text { Pembagian syirkah yang }
$$

disampaikan oleh Zuhaily tersebut senada dengan syirkah yang diungkapkan oleh Firdaus at al., bahwa para ulama membagi syirkah ke dalam bentuk-bentuk dijelaskan di bawah ini. ${ }^{27}$

a. Perserikatan dalam pemilikan (syirkah alamlak), yaitu dua orang atau lebih yang memiliki harta bersama tanpa melalui atau didahului oleh akad syirkah. Musyarakah dalam kategori ini ada dua bagian, yaitu:

1) Syirkah ikhtiar adalah perserikatan yang muncul akibat tindakan hukum orang yang berserikat, seperti dua orang yang bersepakat membeli suatu atau mereka menerima hibah, wasiat, atau wakaf dari orang lain. Mereka menerima pemberian hibah, wakaf ataupun wasiat tersebut dan menjadi milik mereka secara berserikat.

2) Syirkah jabar adalah sesuatu yang disepakati dua orang atau lebih tanpa kehendak. Artinya, perserikatan itu terjadi secara paksa, bukan atas keinginan orang yang berserikat. Contoh, menerima warisan dari orang yang meninggal.

b. Syirkah al-'uqud adalah akad yang disepakati dua orang atau lebih untuk mengikatkan diri dalam perserikatan modal dan keuntungan. Akad tersebut tercipta karena kesepakatan dua orang atau lebih yang setuju bahwa tiap orang dari mereka memberikan modal musyarakah. Merekapun sepakat berbagi keuntungan dan kerugian. Syirkah al'uqud dapat dibagi menjadi: syirkah al'inan, syirkah mufawadhah, syirkah a'mal, dan syirkah wujuh.

Beberapa penelitian terdahulu menunjukkan bahwa praktik pembiayaan musyarakah yang dilakukan oleh BMT ternyata menerapkan produk musyarakah tidak menggunakan prinsip bagi hasil tetapi margin. Berdasarkan tanggapan responden

\footnotetext{
27 Nawawi, Ismail, "Fiqh Muamalah Klasik dan Kontemporer" (Bogor: Ghalia Indonesia, 2012), hlm. 153
} 
ditunjukkan bahwa responden hampir seluruhnya sangat setuju dengan praktik pembiayaan musyarakah. Sedangkan tingkat produktivitas usaha kecil para anggota BMT dari beberapa responden menyatakan sudah sangat baik dengan adanya pembiayaan musyarakah terhadap produktivitas usahanya. Pemberian pembiayaan musyarakah di BMT termasuk dalam kategori pengaruh sedang, dan terdapat hubungan yang signifikan atau dengan kata lain koefisien tersebut dapat digeneralisasikan atau dapat berlaku pada populasi dimana sampel diambil. Berdasarkan hasil penelitian dapat disimpulkan bahwa peningkatan produktivitas usaha kecil dipengaruhi oleh pembiayaan musyarakah sebesar $16,6 \%$ dan sisanya $83,4 \%$ ditentukan oleh faktor lain. Hal ini ditunjukkan dari penelitian Mohamad Ade Saefudin (IAIN Syekh Nurjati Cirebon 2014), begitupun juga penelitian yang dilakukan oleh Fitra Ananda (Universitas Diponegoro Semarang 2011), serta Rani Ernawati (IAIN Walisongo Semarang 2012).

\section{Hasil Penelitian}

Penelitian ini dilakukan di BMT Islamic Centre Kab.Cirebon. Penelitian dilakukan dengan menyebarkan angket kepada 85 responden, yang mana diketahui bahwa responden terbanyak adalah responden berusia 21-30 tahun sebanyak 31 orang atau 36,5\%, kemudian di ikuti responden yang berusia 31-40 tahun sebanyak 25 orang atau $29,4 \%$ kemudian responden berusia 41-50 tahun sebanyak 17 orang atau $20 \%$ dan terakhir responden berusia $>50$ tahun sebanyak 12 orang atau $14,1 \%$. Sedangkan berdasarkan jenis kelamin dapat diketahui bahwa responden terbanyak adalah perempuan sebanyak 63 orang atau $74,1 \%$ dan laki-laki sebanyak 22 orang atau $25,9 \%$. Jika dilihat dari pendidikan terakhirnya responden terbanyak adalah responden SMA sebanyak 55orang atau $64,7 \%$, kemudian diikuti responden berpendidikan SMP sebanyak 17 orang atau $20 \%$, kemudian responden berpendidikan SD sebanyak 10 orang atau $11,8 \%$, Diploma1 orang atau $1,2 \%$ kemudian responden berpendidikan S1 sebanyak 2 orang atau $2,3 \%$. Serta berdasarkan status sosialnya responden yang sudah menikah sebanyak 80 orang atau $94,1 \%$ dan responden yang belum menikah sebanyak 5 orang atau $5,9 \%$. Dengan demikian dapat disimpulkan bahwa nasabah pembiayaan musyarakah di BMT Islamic Centre didominasi oleh responden yang sudah menikah. Adapun analisis mengenai peningkatan pendapatan (bruto) sebelum dan sesudah mendapatkan pembiayaan musyarakah kepada 85 responden tersebut diperoleh hasil yang menunjukkan bahwa terjadi peningkatan pendapatan nasabah yang menjalankan akad pembiayaan musyarakah, hal tersebut terlihat dari adanya perubahan pendapatan dari sebelum memperoleh pembiayaan sampai dengan setelah memperoleh pembiayaan dari BMT Islamic Centre, yakni sebagai bentuk tambahan modal usaha demi terwujudnya perkembangan dan kemajuan usahanya. Penyebab meningkatnya pendapatan nasabah terjadi akibat dari baik penggunaan maupun pengelolaan dana yang tepat atau telah sesuai dengan yang diperuntukkan, yakni untuk tambahan modal usaha misalnya untuk membeli alat-alat usaha, bahan baku, maupun barang-barang tambahan lainnya, serta bukan untuk konsumsi ataupun hal lainnya diluar kegiatan usaha.

Dari hasil penelitian didapatkan hasil bahwa semua variabel valid dan reliabel karena pada uji validitas semua variabel nilai rhitung > rtabel. Dan reliabel karena, semua variabel Alpha Cronbach berada > dari 0,6. Berdasarkan tabel regresi diperoleh persamaan regresi linier sederhana yang terbentuk adalah sebagai berikut:

a. Hasil analisis regresi linier sederhana variabel pembiayaan musyarakah terhadap perkembangan usaha mikro, yaitu:

$\mathrm{Y}=\mathrm{a}+\mathrm{bX}$

$\mathrm{b}=$ Koefisien Regresi

$\mathrm{Y}=11,041+0,227 \mathrm{X}$

b. Hasil analisis regresi linier sederhana variabel pembiayaan musyarakah terhadap pendapatan nasabah, yaitu: 
$\mathrm{Y}=\mathrm{a}+\mathrm{bX}$

$\mathrm{b}=$ Koefisien Regresi

$\mathrm{Y}=13,333+0,151 \mathrm{X}$

Sedangkan pada uji normalitas data, memperoleh nilai signifikansi, yaitu Pembiayaan Musyarakah $(0,068)$, Usaha Mikro (0,184), dan Pendapatan Nasabah $(0,068)$. Yang mana nilai signifikansi masing-masing variabel lebih besar dari 0,05 maka variabel tersebut didistribusikan secara normal. Serta pada uji linearitas nilai signifikansi masing-masing variabel lebih besar dari 0,05 maka dapat disimpulkan bahwa terdapat hubungan yang linear antara variabel $\mathrm{X}$ terhadap variabel $\mathrm{Y}$. Setelah diuji dengan menggunakan uji $\mathrm{T}$, masing-masing secara parsial variabel pembiayaan musyarakah $(\mathrm{X})$ terhadap usaha mikro $\left(\mathrm{Y}_{1}\right)$ dan pendapatan nasabah $\left(\mathrm{Y}_{2}\right)$, sebagai berikut:

a) Pada hasil penelitian menunjukkan bahwa variabel pembiayaan musyarakah berpengaruh positif signifikan terhadap usaha mikro. Dengan nilai $t_{\text {hitung }}>t_{\text {tabel }}$ $(3,039>1,989)$.

b) Pada hasil penelitian menunjukkan bahwa variabel pembiayaan musyarakah berpengaruh positif signifikan terhadap pendapatan nasabah. Dengan nilai $t_{\text {hitung }}>$ $t_{\text {tabel }}(2,231>1,989)$.

Sedangkan untuk mengetahui prosentase sumbang pengaruh variabel independen terhadap variabel dependen, diperoleh hasil yang menunjukkan bahwa prosentase sumbangan pengaruh variabel independen (pembiayaan musyarakah) $\mathrm{R}$ Square 0,100 mampu menjelaskan sebesar $10 \%$ variasi variabel dependen (usaha mikro). Sedangkan sisanya sebesar $90 \%$ dipengaruhi atau dijelaskan oleh variabel yang tidak dimasukkan dalam model penelitian ini. Serta prosentase sumbangan pengaruh variabel independen (pembiayaan musyarakah) $\mathrm{R}$ Square 0,057 mampu menjelaskan sebesar $5,7 \%$ variasi variabel dependen (pendapatan). Sedangkan sisanya sebesar 94,3\% dipengaruhi atau dijelaskan oleh variabel yang tidak dimasukkan dalam model penelitian ini.
Berdasarkan hasil penelitian yang dilakukan, analisis ekonomi yang didapatkan dari penelitian tentang pembiayaan musyarakah dan pengaruhnya terhadap usaha mikro serta pendapatan nasabah. Mengenai pembiayaan musyarakah itu sendiri ada pengaruhnya terhadap usaha mikro yang dijalankan nasabah sebagai tambahan modal usahanya, hal tersebut dapat dilihat dari hasil penelitian di atas melalui beberapa uji dari teknik analisis data yang menyatakan bahwa pembiayaan musyarakah berpengaruh signifikan terhadap usaha mikro nasabah BMT Islamic Centre, dilihat dari dimensi kerja sama berdasarkan prinsip syariah, laba, serta modal usaha. Hasil ini sama dengan hasil penelitian terdahulu yang di teliti oleh Mohamad Ade Saefudin (2014) yang berjudul "pengaruh pembiayaan musyarakah terhadap produktivitas usaha kecil" bahwa terjadi peningkatan produktivitas usaha kecil dilihat dari hasil nilai rata-rata sebesar $73 \%$ yang menyatakan sudah sangat baik dengan adanya pembiayaan musyarakah terhadap produktivitas usahanya.

Pendapatan merupakan hal yang penting, karena pendapatan ini menjadi objek atas kegiatan usaha. Oleh karenanya dalam penelitian ini dibahas mengenai pendapatan nasabah yang dipengaruhi oleh pembiayaan musyarakah, yang mana dana yang diperolehmelalui pembiayaan musyarakah tersebut selain mampu mempengaruhi usaha mikro sebagai tambahan modal usaha juga mampu mempengaruhi pendapatan nasabah sehingga terjadi peningkatan pendapatan. Hal ini dapat dilihat dari hasil penelitian di atas melalui beberapa uji dari teknik analisis data yang menyatakan bahwa pembiayaan musyarakah berpengaruh signifikan terhadap pendapatan nasabah BMT Islamic Centre, dilihat dari dimensi kerja sama berdasarkan prinsip syariah, laba, serta harapan yang terpenuhi. Hasil ini sama dengan hasil penelitian terdahulu yang di teliti oleh Andi Abdullah Sa'ad (2012) yang berjudul "pengaruh pembiayaan murabahah terhadap peningkatan pendapatan nasabah" dari hasil 
uji $\mathrm{t}$ penelitian tersebut diperoleh hasil $\mathrm{t}$ sebesar 4,03 terletak di daerah Ho ditolak. Maka keputusan menolak Ho mengandung arti bahwa ada hubungan atau pengaruh positif yang siginifikan antara pendapatan sebelum pembiayaan murabahah terhadap pendapatan sesudah pembiayaan murabahah.

Dan setelah dilakukan beberapa uji, salah satunya dengan menggunakan uji $t$ diperoleh hasil bahwa antara pengaruh pembiayaan musyarakah terhadap perkembangan usaha mikro dan pendapatan nasabah, hasilnya menunjukkan bahwa pembiayaan musyarakah lebih berpengaruh ke perkembangan usaha mikro dibandingkan dengan pendapatan nasabah. Hal ini ditunjukkan dari besarnya nilai $t_{\text {hitung }}$ antara pembiayaan musyarakah terhadap perkembangan usaha mikro sebesar 3,039 lebih besar dari nilai $t_{\text {hitung }}$ antara pembiayaan musyarakah terhadap pendapatan nasabah sebesar 2,231 (3,039> 2,231).

\section{Penutup}

Dari hasil penelitian tentang pengaruh pembiayaan musyarakah terhadap perkembangan usaha mikro dan peningkatan pendapatan nasabah didapatkan hasil sebagai berikut: Masing-masing secara parsial variabel pembiayaan musyarakah (X) terhadap usaha mikro $\left(\mathrm{Y}_{1}\right)$ dan pendapatan nasabah $\left(\mathrm{Y}_{2}\right)$, sebagai berikut: Pada hasil penelitian menunjukkan bahwa variabel pembiayaan musyarakah berpengaruh positif signifikan terhadap perkembangan usaha mikro nasabah BMT Islamic Centre, dengan nilai $t_{\text {hitung }}>t_{\text {tabel }}(3,039>1,989)$. Artinya bahwa dengan bertambahnya modal usaha melalui pembiayaan musyarakah yang diajukan nasabah ke BMT Islamic Centre mampu untuk mengembangkan usahanya tersebut. Maka, besar kecilnya usaha seseorang sangat dipengaruhi oleh besar kecilnya modal yang dipergunakan. Serta hasil penelitian menunjukkan bahwa variabel pembiayaan musyarakah berpengaruh positif signifikan terhadap pendapatan nasabah BMT Islamic Centre, ditunjukkan dari nilai $t_{\text {hitung }}>t_{\text {tabel }}(2,231>1,989)$. Artinya dengan bertambahnya modal melalui pembiayaan musyarakah berarti terjadi peningkatan pada pendapatan nasabah melalui kegiatan usaha yang mereka jalankan tersebut. Karena suatu pendapatan dipengaruhi dengan adanya berbagai faktor yaitu: kesempatan kerja yang tersedia, jenis pekerjaan juga mempengaruhi suatu pendapatan, kecakapan dan keahlian, motivasi atau dorongan, keuletan kerja, serta banyak sedikitnya modal yang digunakan. Dan dari analisis tersebut dapat disimpulkan bahwa antara pengaruh pembiayaan musyarakah terhadap perkembangan usaha mikro dan pendapatan nasabah, hasilnya menunjukkan bahwa pembiayaan musyarakah lebih berpengaruh ke perkembangan usaha mikro dibandingkan dengan pendapatan nasabah. Hal ini ditunjukkan dari besarnya nilai $t_{\text {hitung }}$ antara pembiayaan musyarakah terhadap perkembangan usaha mikro sebesar 3,039 lebih besar dari nilai thitung antara pembiayaan musyarakah terhadap pendapatan nasabah yakni sebesar 2,231 $(3,039>2,231)$.

Saran-saran yang dapat diberikan sebagai tindak lanjut hasil penelitian adalah selain memberikan penjelasan mengenai sistem bagi hasil, hendaknya BMT Islamic Centre memberikan gambaran tentang resiko yang dihadapi nasabah ketika calon nasabah memutuskan untuk menjadi nasabah pembiayaan musyarakah tersebut, hendaknya BMT Islamic Centre memberikan penjelasan mengenai perbedaan bunga dan bagi hasil kepada calon nasabah, sehingga dapat meyakinkan nasabah bahwa pembiayaan yang diterimanya tidak terdapat unsur riba, serta hendaknya BMT Islamic Centre melakukan sosialiasi mengenai bagaimana cara penggunaan dana dari pembiayaan musyarakah yang efektif dan efisien, supaya tidak terjadi penyalahgunaan dana yang mengakibatkan tidak tercapainya tujuan utama dari pembiayaan tersebut, yakni untuk tambahan modal usaha. Sehingga diharapkan dapat berdampak pada perekonomian nasabah yang lebih baik. 


\section{Daftar Pustaka}

A. Karim, Adiwarman, "Bank Islam Analisis Fiqh dan Keuangan" (Jakarta: PT. Raja Grafindo Persada, 2013)

Abdul Rahman Ghazaly, dkk, "Fiqh Muamalat” (Jakarta: Kencana Prenada Media Group, 2010)

Agus Irianto, "STATISTIK: Konsep Dasar, Aplikasi, dan Pengembangannya" (Jakarta: Kencana, 2010)

Ali, Zainuddin, "Hukum Perbankan Syariah" (Jakarta: Sinar Grafika, 2010)

Anshori, Abdul Ghofur, "Hukum Perbankan Syariah” (Bandung: PT. Refika Aditama, 2009)

Arsyad, Lincolin, "Lembaga Keuangan Mikro" (Yogyakarta: Andi Offset, 2008)

Basir, Cik, "Penyelesaian Sengketa Perbankan Syariah" (Jakarta: Kencana, 2009)

Budisantoso, Totok, "Bank dan Lembaga Keuangan lain edisi 2: Bank Umum Berdasar Prinsip Syari'ah" (Jakarta: Penerbit Salemba Empat, 2006)

Bungin, Burhan, "Metodologi Penelitian Kuantitatif" (Jakarta: Kencana Prenada Media Group, 2005)

Burhanuddin, “Aspek Hukum Lembaga Keuangan Syariah" (Yogyakarta: Graha Ilmu, 2010)

E.Nasution, Mustafa, dkk, "Pengenalan Eksklusif Ekonomi Islam” (Jakarta: Kencana, 2006)

Hadinoto, Soetanto, Kiat Memimpin Bank Ritel, Mikro, dan Konsumer (Jakarta: PT. Elex Media Komputindo, 2009)

Ismail, "Perbankan Syariah" (Jakarta: Kencana, 2011)

Karim, Adiwarman, "Bank Islam Analisis Fiqih dan Keuangan” (Jakarta: Raja Grafindo, 2013)

Martani, dwi, dkk, "Akuntansi Keuangan Menengah Berbasis PSAK” (Jakarta: Salemba Empat)

Mudrajad Kuncoro, "Metode Riset Untuk Bisnis \& Ekonomi, Edisi Keempat" (Jakarta: Erlangga, 2013)
Muhamad, "Metodologi Penelitian Ekonomi Islam Pendekatan Kuantitatif" (Jakarta: Rajawali Pers, 2013)

Muhammad, "Bank Syariah Problem dan Prospek Perkembangan di Indonesia" (Yogyakarta: Graha Ilmu, 2005)

Nawawi, Ismail, "Fiqh Muamalah Klasik dan Kontemporer" (Bogor: Ghalia Indonesia, 2012)

Nur Asnawi dan Masyhuri, "Metodologi Riset Manajemen Pemasaran" (Malang: UIN Maliki Press, 2011)

Nurul Huda dan Mohamad Heykal, "Lembaga Keuangan Islam:Tinjauan teoretis dan praktis" (Jakarta: Kencana, 2010)

Ratna, Sukmayanti, dkk, "Ilmu Pengetahuan Sosial” (Jakarta: Galaxy Puspa Mega, 2008)

Riduwan dan Engkos Achmad Kuncoro,"Cara Menggunakan dan Memaknai Analisis (Path Analysis)" (Bandung: Alfabeta, 2008)

Ridwan, "Belajar Mudah Penelitian Untuk Guru, Karyawan, Dan Peneliti Pemula” (Bandung: Alfabeta, 2008)

Rivai, Veithzal, "Islamic Financial Management” (Jakarta: PT Raja Grafindo, 2008)

Saeed, Abdullah, "Bank Islam dan Bunga" (Yogyakarta: Pustaka Pelajar, 2003)

Sekaran, Umar, "Metode Penelitian Untuk Bisnis Edisi Keempat"(Jakarta: Salemba Empat. 2000)

Siregar, Syofian, "Statistik Parametrik Untuk Penelitian Kuantitatif” (Jakarta: Bumi Aksara, 2014)

Soemitra, Andri, "Bank dan Lembaga Keuangan Syariah” (Jakarta: Kencana Prenada Media Group, 2009)

Sri Nurhayati dan Wasilah, "Akuntansi Syariah di Indonesia” (Jakarta: Salemba Empat, 2009)

Sudarsono, Heri, "Bank dan Lembaga Keuangan Syariah” (Yogyakarta: Ekonosia)

Sugiyono, "Metode Penelitian Kuantitatif dan R\&D” (Bandung: Alfabeta, 2012) 
Suharyadi dan Purwanto, "Statistika Untuk Ekonomi \& Keuangan Modern" (Jakarta: Salemba Empat, 2003)

Sukirno, Sadono, "Mikroekonomi Teori Pengantar” (Jakarta: PT Raja Grafindo Persada, 2013)

Wirdyaningsih, dkk, "Bank dan Asuransi Islam di Indonesia” (Jakarta: Kencana, 2005)

Yahya, Rizal, dkk, "Akuntansi Perbankan Syariah” (Jakarta: Salemba Empat, 2009) http://duwiconsultant.blogspot.co.id/2011/11 /analisis-regresi-linier-sederhana.html diakses 17 mei 2017 pkl 10.00

http://www.matabaraja.com/2016/10/pengert ian-pengembangan-bisnismenurut.html diakses 22 Mei 2017 pkl 9.42

http://www.spssindonesia.com/2014/02/ujilinearitas-dengan-program-spss.html diakses 22 Mei 2017 pkl 9.13 